\title{
Extreme Climate Events and Fish Production in Bangladesh
}

\author{
Jatish C. Biswas ${ }^{1}$, M. Maniruzzaman², M. M. Haque 2 , M. B. Hossain², \\ M. M. Rahman ${ }^{3}$, U. A. Naher ${ }^{2}$, M. H. Ali ${ }^{4}$ \& W. Kabir ${ }^{4}$ \\ ${ }^{1}$ Soil Science Division, BRRI \& Coordinator, CRP-II, KGF, Dhaka, Bangladesh \\ ${ }^{2}$ BRRI, Gazipur, Bangladesh \\ ${ }^{3}$ BSMRAU, Gazipur, Bangladesh \\ ${ }^{4}$ Krishi Gobeshona Foundaion (KGF), Dhaka, Bangladesh \\ Correspondence: M. M. Haque, BRRI, Gazipur, Bangladesh. Tel: 880-171-813-3016. E-mail: \\ mhaquesoil@yahoo.com
}

Received: November 6, 2018

Accepted: December 14, 2018

Online Published: December 17, 2018

doi:10.5539/enrr.v9n1p1

URL: https://doi.org/10.5539/enrr.v9n1p1

\begin{abstract}
Natural hazards frequently batter Bangladesh and cause damages to fisheries sector of the country. The main objective of the present investigation was to evaluate the effects of storm/tidal surge, waterlogging, cyclone, flood, drought and erosion on spatial distribution of damages and economic loss in fisheries of Bangladesh. Data were collected from existing literatures followed by scoring and attribute-wise maps were prepared using IDRISI3.2. The highest economic loss (US\$ 17.65 million) in fishery sector was observed in Southern part and the least in hilly regions. The damages caused by natural hazards followed the order of storm/tidal surge $>$ waterlogging $>$ cyclone $>$ flood $>$ drought $>$ erosion. About $21 \%$ areas of South and South-east Bangladesh were affected by high to very high storm/tidal surge. Very severe waterlogging problems were observed in $6.96 \%$ areas of the country. Moderate to high damages because of cyclone were found in about $11 \%$ areas in South and South-east Bangladesh. Moderate to high flooding problems were mostly prevalent in Central and North-east part of the country covering 15-19 per cent areas. Drought and erosion are less damaging to fishery sector compared to other studied natural hazards. Although exposure index to natural hazards is high, relative index to national economy because of damages to fisheries sector are low. Adaptive measures in coastal areas as a long-term strategy would be participatory construction of hard structures and reclamation/conservation of wetlands throughout the country including improved warning system could be undertaken for minimizing damages in fisheries sector of Bangladesh.
\end{abstract}

Keywords: Storm/Tide, Waterlogging, Cyclone, Flood, Drought, Erosion, Area

\section{Introduction}

Total inland areas in Bangladesh are 6.7 million hectares of which $94 \%$ are used for open water capture fishery and $6 \%$ for closed water culture. Seasonal flooding of 4-6 months extends fish culture areas over 5.5 million hectares. Marine fisheries also contribute to the national economy of Bangladesh, though not yet effectively utilized the marine resources. In 2016-17, marine fisheries catch was about 0.64 million ton that was only $15.42 \%$ of total fish production in Bangladesh (YFSB, 2017). Fisheries help in providing livelihood for more than 11\% people of the country (DoF, 2016) and fish stocks are under pressure from construction of barrages, dams, over exploitation, pollution, erosion, introduction of exotic stocks, etc. Nonetheless, fisheries contribute $3.65 \%$ of national gross domestic product (GDP), which is $23.81 \%$ to agricultural GDP (FRSS, 2016) and $2.01 \%$, to total export (DoF, 2015). About 60\% of protein requirement in Bangladesh is fulfilled from fish (Hossain, 2014). The most striking feature of this sector is that $80 \%$ of the workers for fish processing and drying are women (DoF, 2013) and thus empowering them economically in the society. However, the major stakeholders are fish farmers, prawn/shrimp farmers, hatchery owner, input traders, nurserer, feed mill owners, exporters, retailers, consumers, technical support providers and others. So, any damage to this sector influences many stakeholders' livelihood.

Bangladesh, a low-lying country, is highly vulnerable to sea level rise specifically the coastal areas because of climate change impact (Kabir et al., 2016). The impacts can directly or indirectly damage fisheries sector. For example, drought and siltation reduce water reservoir capacity and thus play an important role in decline of riverine fisheries. Besides, many riverbeds are converting to crop fields, brick kilns, etc resulting in reduced fish diversity (Hossain, 2014). Fish physiology, growth, reproduction, mortality and distribution are also changing because of 
climatic change impact (Sumaila et al., 2011). Moreover, aquatic habitats are adversely affected by urbanization, deforestation, pollution and so on (Al Shami et al., 2011). Migratory fishes can't complete life cycle if waterways are obstructed by making dam or other structures and thus adversely affects annual population recruitment (Antonio et al., 2007; Hossain, 2014).

The floodplain and marine fisheries are under grave threat from overfishing and increasing the dependency on distant water fishing (Ghose, 2014) along with changes in temperature, freshwater ecosystems, and precipitation that greatly influences fish stocks. Storm would be more frequent and extreme destroying habitats, stocks and livelihoods (WorldFish, 2007). There are few literatures available on fisheries vulnerability for small areas (Kabir et al., 2016; Hasan \& Bhowmik, 2016; Islam et al., 2014) or effects of limited numbers of natural hazards on fisheries and social communities in Bangladesh (Hossain, 2014; Ghose, 2014). Therefore, the objectives of the present investigation are to evaluate damage patterns in fishery sector because of climate change induced natural hazards, spatial distribution of damages and to provide some policy guidelines for adaptation.

\section{Materials and Methods}

Data were collected from Bangladesh Bureau of Statistics, Center for Geographic Information Services (CEGIS, 2013), Department of Fisheries, Bangladesh Agricultural Research Council (http://www.barc.gov.bd/), and Bangladesh Delta Plan-2100 (GED, 2017) and from existing available literatures. Data on fish production and the effects of flood, drought, cyclone, storm/tidal surge, waterlogging and erosion on economic losses during 20092014 were collected (BBS, 2015) for delineating vulnerable areas. Data were collected from 64 districts based on stratified two-stage random sampling technique. A total of 4945 mauzas/mahallas (the smallest administrative unit) were selected out of 21892 and then 143980 households were selected for data collection. Pre-tested questionnaire was used in seven districts followed by necessary modifications for data collection (BBS, 2015). Drought mostly affects all living beings in Bangladesh during dry season and so we have considered this season for fish vulnerability assessment. We have collected waterlogging data from GED, 2017; BBS, 2017; FAO, 2014; BADC, 2009-2010 and other published literatures followed by scoring based on intensities of damages as duration of waterlogging and area affected. The hotspots of natural hazards and area coverage were determined based on total score either as district or Upazila (administrative unit within a district) based. Scoring criteria are shown in Table 1 and 2. If a district was exposed to different levels of intensity of a natural hazard (say flooding), average score was made out of total score. The lowest score indicates the least vulnerable area and then gradually increased. Attribute-wise maps were prepared using IDRISI3.2.

Table 1. Scoring system for flood, cyclone and drought in Bangladesh

\begin{tabular}{lllll}
\hline $\begin{array}{l}\text { Flooding } \\
\text { Depth (M) }\end{array}$ & Score & $\begin{array}{l}\text { Cyclone } \\
\text { Category }\end{array}$ & Score & $\begin{array}{l}\text { Drought } \\
\text { Category }\end{array}$ \\
\hline No flooding & 1 & No risk & 1 & Slight/no drought \\
$<0.3$ & 2 & High wind speed & 2 & Moderate \\
$0.3-0.91$ & 3 & Medium risk & 3 & Severe \\
$0.91-1.83$ & 4 & High risk & 4 & Very severe \\
$1.83-3.05$ & 5 & & & 4 \\
$>3.05$ & 6 & & & \\
\hline
\end{tabular}

Table 2. Scoring criteria for erosion, storm/tidal surge and waterlogging

\begin{tabular}{|c|c|c|c|c|c|}
\hline Erosion (ha) & Score & Storm/tidal surge & Score & Waterlogging & Score \\
\hline$<1000$ & 10 & Very low/no & 1 & Very low/no & 1 \\
\hline $1000-2000$ & 20 & Low & 2 & Moderate & 2 \\
\hline $2000-5000$ & 40 & High & 3 & Severe & 3 \\
\hline $5000-15000$ & 70 & Very high & 4 & Very severe & 4 \\
\hline$>15000$ & 100 & & & & \\
\hline
\end{tabular}

\section{Results}

The highest economic loss (>1500 million taka, MTk; US\$ 17.65 million) in fishery sector was observed in southern part (about $4 \%$ areas) and the least in hilly regions of the country (Figure 1). Some districts in the north and central part of the country (89.23\%) faced economic loss in the range of $<5$ to 100 MTk (0.06-1.2 million US\$). The huge losses in fishery sector were related with severity of storm/tidal surge $>$ waterlogging $>$ cyclone $>$ flood $>$ drought $>$ erosion, but the damaging effects of flood were quite noticeable in all over the country (Figure 2). 


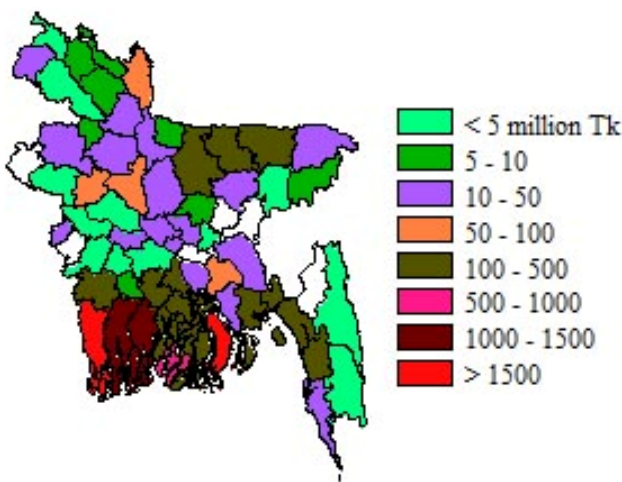

Figure 1. Economic loss in fish sector because of natural hazards in Bangladesh

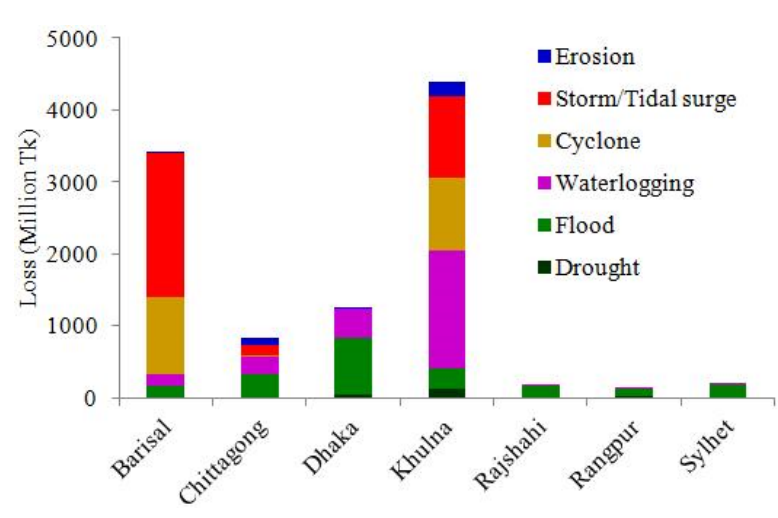

Figure 2. Division wise loss in fishery sector because of natural hazards in Bangladesh

Source: (BBS, 2015).

About $21 \%$ areas of south and south-east Bangladesh were affected by high to very high storm/tidal surge categories (Figure 3a). Moderate, severe and very severe waterlogging problems were observed in $29.68 \%, 4.31 \%$ and $6.96 \%$ areas of the country, respectively (Figure $3 \mathrm{~b}$ ). Moderate to high damages because of cyclone were found in $10.84 \%$ and $11.52 \%$ areas, respectively in south and south-east Bangladesh (Figure $4 \mathrm{a}$ ). Moderate to high flooding problems are mostly prevalent in central and north-east of the country covering about 15-19 percent areas of the country. Flood free zone is about $7 \%$ and very low to low flooding generally occurs in about $24 \%$ and $15.71 \%$ areas, respectively (Figure $4 \mathrm{~b}$ ). Slight/no drought covers about $44.42 \%$ areas; moderate, severe and very severe droughts were observed in $21.09 \%, 17.36 \%$ and $17.12 \%$ areas of the country, respectively (Figure 5a). Very severe drought hotspots are mostly distributed in north-west part of the country. Moderate to very high erosions were mostly found in big river flow areas, which could be 6-10 per cent of the country (Figure 5b).
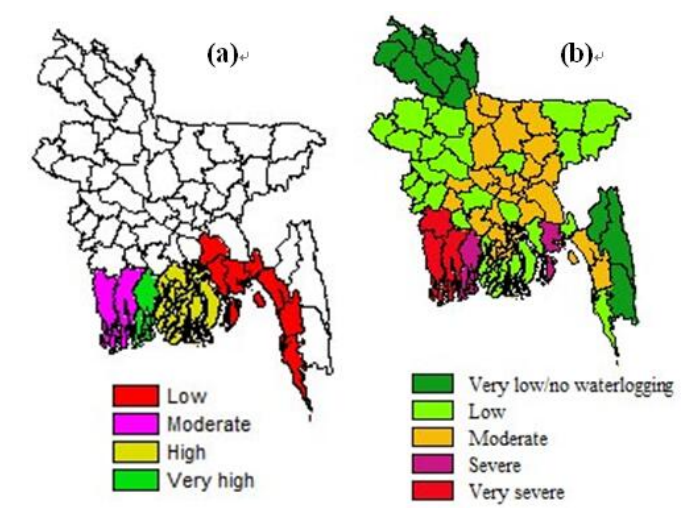

Figure 3. Vulnerable areas for fisheries sector because of (a) storm/tidal surge and (b) waterlogging in Bangladesh

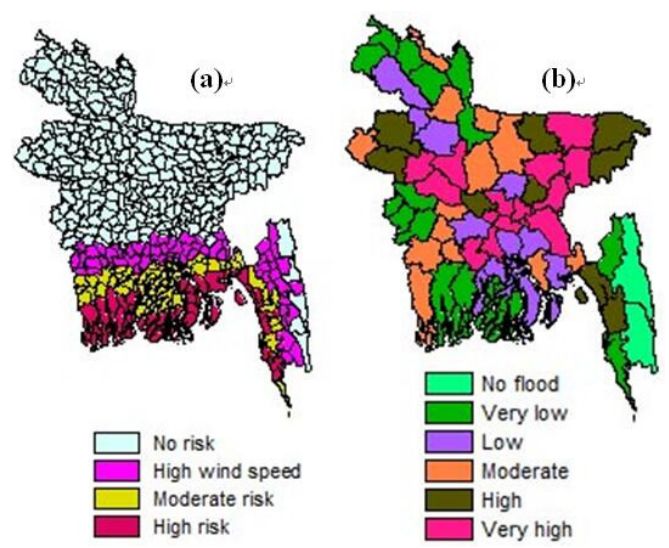

Figure 4. Hotspots for damages in fish production because of (a) cyclone and (b) flood in Bangladesh 

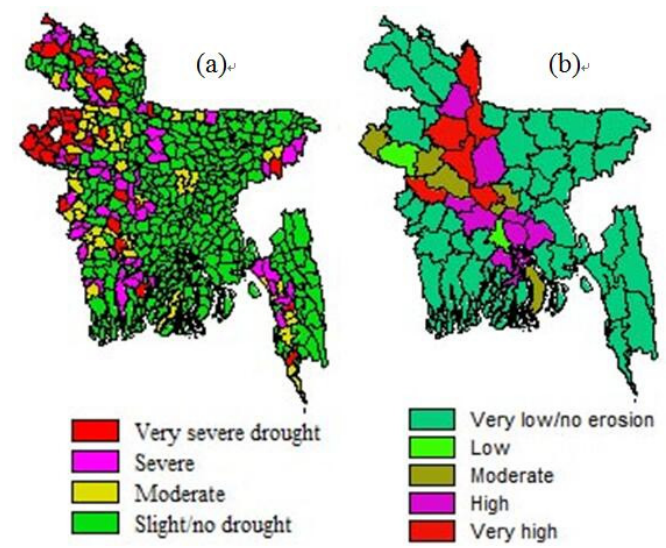

Figure 5. Vulnerable zones for fishery sector because of (a) drought and (b) erosion in Bangladesh

\section{Discussion}

Economic losses in fishery and aquaculture sectors are high because of occurrences of natural calamities very frequently depending on locations of the country. Sensitivity to exposed hazards depends on financial capabilities of stakeholders and intensity of natural calamities. Azad and Wadood (2017) also reported that stakeholders having low income in Dhaka, Rangpur and Khulna divisions are more vulnerable to climate change related shock than other parts of the country. The economic shock could be immediate and long term because ponds, gher, etc can remain uncultivable for years together after severe cyclone, storm/tidal surge (Dasgupta et al., 2010; Mallick et al., 2011). To minimize such economic losses fishers try to catch more resulting in overfishing that in turn is responsible stock collapses. Moreover, overfishing reduces revenues and economic efficiencies and increased variability (Hsieh et al., 2006). The major natural hazards that mostly govern economic losses in fishery sector are storm/tidal surge and waterlogging. Despite all these odds, fish production is increasing in Bangladesh. During 2013-14 fish production was quite satisfactory in different parts of the country ranging from $<200$ to 3500000 tons in a district (Figure 6).

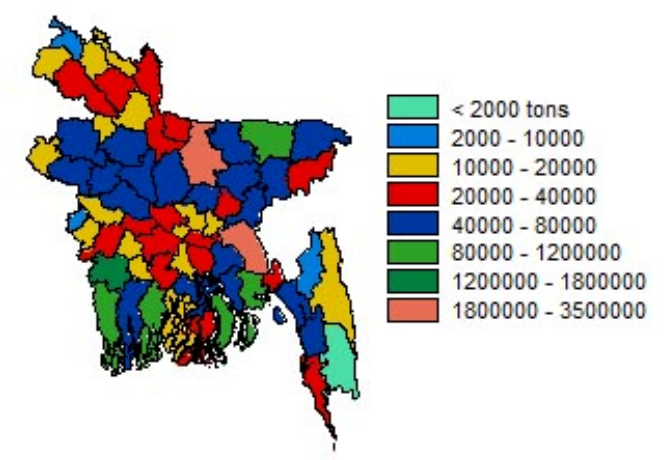

Figure 6. Total fish production in Bangladesh during 2013-14

Source: (BBS, 2017).

Fisheries located in deltas, like Bangladesh, will be exposed to frequent distribution or intensity of tropical cyclones because of climate change impacts and the damages will vary depending on the ability of individual fishers or systems to adapt (IPCC, 2007; Daw et al., 2009). Historically, out of 508 cyclones formed in the Bay of Bengal, $17 \%$ made landfall in Bangladesh and one of them was extreme in nature in every three years (Saha \& Khan, 2014) resulting in huge economic losses. Tidal surge water rises up to several meters during cyclonic events and washed out fisheries and destroy other flora and fauna (Karim \& Mimura, 2008; Ahmed et al., 2012). In future, fisheries of coastal areas will be more vulnerable to sea level rise and associated risks of flooding, saline water intrusion and erosion (Nicholls et al., 2007b). Besides, non-climate factors can increase vulnerability by affecting exposure, sensitivity and adaptive capacity of the system (Adger et al., 2007). It was found from the predicted analysis that exposure to natural calamities for Bangladesh will be very high having somewhat adaptive capacity 
and relatively low vulnerability and sensitivity to national economy because of damages by natural hazards on fishery sector in Bangladesh (Figure 7).

Waterlogging is a chronic problem of southern Bangladesh mostly because of congested drainage systems associated with river siltation and faulty management of polder systems (Kallen et al., 2009). It is also aggravated because of unusual flooding duration, tidal surge and cyclones; but technology induced aquaculture in communitybased ponds and waterlogged paddy lands are providing good returns in total fish production of Bangladesh (Hasan \& Bhowmik, 2016). However, in almost every year cyclone hits Bangladesh coastal areas in different degrees of intensities, which could be increased by $5-10 \%$ in future with $20-30 \%$ higher precipitation (IPCC, 2001) and thus more fishers will be affected in future. The cyclones not only destroy human settlement, but also cause temporary decline in the abundance of some fishes because of loss of critical habitat of food (Wilson et al., 2006). For example, cyclone Sidr and Aila affected coastal fishery and fishing ground severely in Bangladesh.

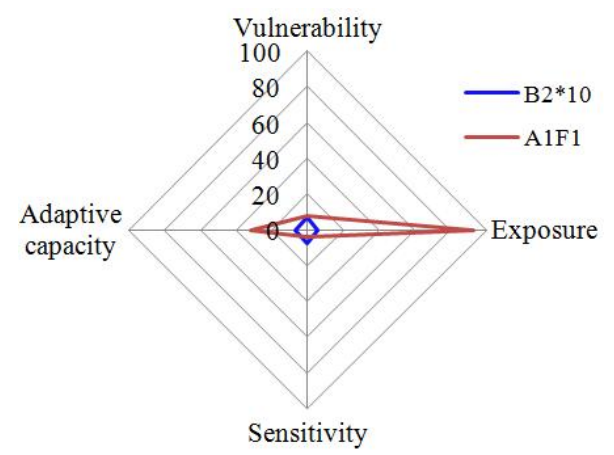

Figure 7. Relative vulnerability of economy of Bangladesh because of climate change induced impacts on fisheries (Adopted from ICTSD, 2009)

B2*10 indicates local development and less emissions, 10 times higher values shown A1F1 indicates rapid development and high emissions.

Flooding is the historic events in Bangladesh. There will be damages either from flash flood, river flooding or flood from cyclone and tidal surges. Flooded areas could be greater in wet season by $20-40$ per cent and fish production may be increased by 60000-130000 t yr ${ }^{-1}$ (Allison et al., 2005); but dry season in Bangladesh offset such benefit because of reduced water flow from Transboundary Rivers and high evapotranspiration demand. Moreover, under climate change scenario about $18 \%$ of current lowly flooded areas will be susceptible to higher levels of flooding and there will be risk for flooding of $12-16 \%$ new areas in a normal hydrological year (Ahmed, 2006) and thus likely to increase sufferings of land animals and human beings.

The contributions of drought and erosion to the economic losses in fishery sector are the least compared to other natural hazards that prevail in Bangladesh; but more intense droughts are prevailing in North-west Bangladesh (Figure 5a) resulting in loss of both wild and farmed fish stocks (Hossain, 2014). Erosion and accretion of lands take place nearby rivers areas of Padma, Brahmaputra, Meghna, and Jamuna resulting in loss of ecosystem for fish production.

\section{Adaptation strategies}

Preventive measures are effective against direct impacts of extreme events on fisheries infrastructure and communities (Nicholls et al., 2007a). Adaptations to increased storm and tidal surge could be embankment and restoration of wetlands. Options for diversified fish products and market systems can alleviate economic shocks (FAO, 2007b). Investments in generic adaptive capacity would be good option for the future in fisheries sector, but is has to be initiated. Best managed fisheries sector are expected to have greater adaptive capacity, although adaptation strategy from other sectors in a particular area may affect adversely other areas. For example, flood mitigation measures in Bangladesh negatively affected fisheries (Shankar et al., 2004) through sediment loading which are seen in polder areas of Bangladesh.

Aquaculture are playing a good role in total fish production of Bangladesh, which has been increased over the last 30 years (Hasan \& Bhowmik, 2016) but still lacking efficient management systems. So, proper management 
strategies need to be developed for sustainable aquaculture practices in Bangladesh. In general, following points may also be considered for adaptation strategies in Bangladesh:

- Capacity building for survey works,

- Regional cooperation,

- Regulation of fishing by dewatering,

- Establishment of more sanctuaries both for marine and inland fisheries,

- Improvement in information delivery systems for awareness build up for emergency preparedness,

- Promoting salt tolerant fish culture in coastal areas,

- Prevention of water pollution, and

- Strict execution of existing fisheries rules and regulations

\section{Conclusion}

Influences of climate extremes, storm/tidal surge, waterlogging, cyclone, flood, drought and erosion on damages in fisheries sector of Bangladesh were investigated based on existing literatures. Scoring techniques were employed depending on severity of damages and attribute-wise maps were prepared using IDRISI3.2. The highest economic loss (US\$ 17.65 million) in fishery sector was observed in Southern part of Bangladesh and the gradual decrease of damages followed were storm/tidal surge $>$ waterlogging $>$ cyclone $>$ flood $>$ drought $>$ erosion. About $21 \%$ areas of South and South-east Bangladesh were affected by high to very high storm/tidal surge and very severe waterlogging problems were observed in $6.96 \%$ areas of the country. Government has taken some measurements for adaptation against natural hazards that need to be strengthened because the frequencies of climate extremes are increasing in Bangladesh. Best management options need to be sorted out for sustained production in aquaculture along with capacity enhancement of fisheries sectors.

\section{Acknowledgements}

We acknowledge financial contribution of Krishi Gobeshona Foundation (KGF) through the project on Modelling Climate Change Impact in Bangladesh (CRP-II).

\section{Conflict of interests}

The authors declare that there is no conflict of interests regarding the publication of this paper.

\section{References}

Adger, W. N., Agrawala, S., Mirza, M. M. Q., Conde, C., .. \& Takahashi, K. (2007). Assessment of adaptation practices, options, constraints and capacity. In M. L. Parry, O. F. Canziani, J. P. Palutikof, C. E. Hanson \& P. J. van der Linden (Eds.), Climate change 2007: Impacts, adaptation and vulnerability (pp. 719-743). Contribution of working group II to the Fourth Assessment Report on the Intergovernmental Panel on Climate Change. Cambridge, UK, Cambridge University Press.

Ahmed, A. U. (2006). Bangladesh: Climate Change Impacts and Vulnerability A Synthesis. Climate Change Cell, Department of Environment. Component 4b. Comprehensive Disaster Management Programme, Bangladesh. Room 4003, Paribesh Bhavan, Agargaon, Dhaka-1207, Bangladesh.

Ahmed, A., Rahman, M. M., \& Faisal, M. A. (2012). Reducing cyclone impacts in the coastal areas of Bangladesh: A case study of Kalapara Upazila. Journal of Bangladesh Institute of Planners, 5, 185-197.

Allison, J. D., Abell, R., Hogan, Z. E. B., Revenga, C., ... \& Winemiller, K. (2005). Overfishing of inland waters. Biological Sciences, 55, 1041-1051.

Al-Shami, S. A., Rawi, C. S. M., Ahmad, A. H., Hamid, S. A., \& Nor, S. A. M. (2011). Influence of agricultural, industrial and anthropogenic stresses on the distribution and diversity of macro invertebrates in Juru river basin, Penang, Malaya. Ecotoxicology and Environmental Safety, 74, 1195-1202.

Antonio, R. R., Agostinho, A. A., Pelicice, F. M., bailly, D., ..., \& Dias, J. H. P. (2007). Blockage of migration routes by dam construction: Can migratory fish find alternative routes? Neotrop Ichthyol, 5, 177-184.

Azad, A. K., \& Wadood, S. N. (2017). Climate change and Bangladesh fisheries and aquaculture: Evidences from the household income and expenditure survey (HIES) 2010 data. MPRA Paper No. 81552. Retrieved from http://mpra.ub.uni-muenchen.de/81552/

BADC (Bangladesh Agricultural Development Corporation). (2009-2010). Program for removing waterlogging and increasing agriculture production in different districts. Annual Report 2009-2010 (pp. 72-80). BADC. 
BBS (Bangladesh Bureau of Statistics). (2016). Bangladesh Disaster-related Statistics 2015: Climate Change and Natural Disaster Perspectives. Statistics and Informatics Division, Ministry of Planning, Government of the People's Republic of Bangladesh (pp. 165-171).

BBS (Bangladesh Bureau of Statistics). (2017). Statistics and Informatics Division, Ministry of Planning, Government of the People's Republic of Bangladesh (36th ed.).

CEGIS (Center for Environmental and Geographic Information Services). (2013). Vulnerability to climate induced drought: Scenario and Impacts (p. 134).

Dasgupta, S., Huq, M., Khan, Z. H., Ahmed, M. M. Z., ... \& Pandey, K. D. (2010). Vulnerability of Bangladesh to cyclones in a changing climate: Potential damages and adaptation cost. World Bank Policy Research Working Paper Series, 5280.

Daw, T., Adger, W. N., Brown, K., \& Badjeck, M. C. (2009). Climate change and capture fisheries: Potential impacts, adaptation and mitigation. In K. Cochrane, C. De Young, D. Soto, \& T. Bashri (Eds.), Climate Change Implications for Fisheries and Aquaculture: Overview of Current Scientific Knowledge (pp. 107150). FAO Fisheries and Aquaculture Technical Paper No. 530. Rome, FAO.

DoF (Department of Fisheries). (2013). Matshya Saptaha Saranika-2012. Department of Fisheries, Ministry of Fisheries and Livestock. The Government of the People's Republic of Bangladesh, Ramna, Dhaka. Bangladesh, 144.

DoF (Department of Fisheries). (2015). National fish week, 2015. Compendium, Department of Fisheries, Ministry of Fisheries and Livestock, Bangladesh, 148.

DoF (Department of Fisheries). (2016). National fish week, 2016. Compendium, Department of Fisheries, Ministry of Fisheries and Livestock, Bangladesh, 148.

FAO (Food and Agriculture Organization). (200b). Information and communication technologies benefit fishing communities. New Directions in Fisheries-A Series of Policy Brief on Development Issues, 9, 16. Rome, FAO. Retrieved from http://www.sflp.org.briefs/eng/ policybriefs.html

FAO (Food and Agriculture Organization). (2014). The State of the World Fisheries and Aquaculture 2014 (p. 223). Rome.

FRSS (Fisheries Resource Survey System). (2016). Fisheries Statistical Report of Bangladesh, Department of Fisheries, Bangladesh, 32, 57.

GED (General Economics Division). (2017). Hotspots wise problems and challenges. Bangladesh Delta Plan 2100. Bangladesh Planning Commission. Government of the People's Republic of Bangladesh, 154-158.

Ghose, B. (2014). Fisheries and Aquaculture in Bangladesh: Challenges and opportunities. Annals of Aquaculture and Research, 1, 1001.

Hasan, M. M., \& Bhowmik, S. (2016). Impact of climate change on socio-economics of aquaculture in the district of Noakhali, Bangladesh. Journal of Aquaculture Research and Development, 7, 9.

Hossain, M. A. R. (2014). An overview of fisheries sector of Bangladesh. Research in Agriculture Livestock and Fisheries, 1, 109-126.

Hsieh, C. H., Reiss, C. H., Hunter, C. S., Beddington, J. R., ... \& Sugihara, G. (2006). Fishing elevates variability in the abundance of exploited species. Nature, 443, 859-862.

ICTSD (International Center for Trade and Sustainable Development). (2009). Climate change and fisheries: Policy, trade and sustainable development issues. Information Note, (15), 8.

IPCC (Intergovernmental Panel on Climate Change). (2001). Climate Change 2001: Mitigation, Contribution of Working Group III to the Third Assessment Report of the IPCC. Cambridge University Press, UK.

IPCC (Intergovernmental Panel on Climate Change). (2007). Summary for policymakers. In M. L. Parry, O. F. Canziani, J. P. Palutikof, P. J. vd Linden, \& C. E. Hanson (Eds.), Climate Change 2007: Impacts, adaptation and vulnerability. Contribution of Working Group II to the Fourth Assessment Report of the IPCC (pp. 7-22). Cambridge University Press, Cambridge, UK.

Islam, M., Sallu, S., Hubacek, K., \& Paavola, J. (2014). Limit and barriers to adaptation to climate variability and change in Bangladeshi coastal fishing communities. Marine Policy, 43, 208-216.

Kabir, R., Khan, H. T. A., Ball, E., \& Caldwells, K. (2016). Climate change impact: The experience of the coastal areas of Bangladesh affected by cyclones Sidr and Aila. Journal of Environmental Public and Health, 2016. 
Kallen, M. J., Kuniewski, S. P., \& Noortwijk, J. M. (2009). Risk and Decision Analysis in Maintenance Optimization and Flooding Management. Amsterdam: IOS Press

Karim, M. F., \& Mimura, N. (2008). Impacts of climate change and sea level rise on cyclonic storm surge flood in Bangladesh. Global Environmental Change, 18, 490-500.

Mallick, B., Rahman, K. R., \& Vogt, J. (2011). Coastal livelihood and physical infrastructure in Bangladesh after cyclone Aila. Mitigation and Adaptation. Strategies for Global Change, 16, 629-648.

Nicholls, R. J., Hanson, S., Herweijer, C. C., Patmore, N., ... \& Muir-Wood, R. (2007a). Ranking port cities with high exposure and vulnerability to climate extreme: Exposure estimates. OECD Environment Working Paper, (1), 64. Retrieved from http://www.oecd.org/dataoecd/16/58/39720578.pdf

Nicholls, R. J., Wong, P. P., Burkett, V. R., Codignotto, J. O., ... \& Woodroffe, C. D. (2007b). Coastal systems and low-lying areas. In M. L. Parry, O. F. Canziani, J. P. Palutikof, P. J. vd Linden, \& C. E. Hanson (Eds.), Climate Change 2007: Impacts, adaptation and vulnerability (pp. 315-356). Contribution of Working Group II to Fourth Assessment Report of The IPCC, Cambridge Univ. Press, Cambridge, UK.

Saha, M. K., \& Khan, N. A. (2014). Changing profile of cyclones in the context of climate change and adaptation strategies in Bangladesh. Journal of Bangladesh Institute of Planners, 7, 63-78.

Shankar, B., Halls, A., \& Barr, J. (2004). Rice versus fish revisited: On the integrated management of floodplain resources in Bangladesh. Natural Resources Forum, 28, 91-101.

Sumaila, U. R., Cheung, W. W. L., Lam, V. W. Y., Pauly, D., \& Herrick, S. (2011). Climate change impacts on the biophysics of the world fisheries. Nature Climate Change, 1, 449-456.

Wilson, S. K., Graham, N. A. J., Pratchett, M. S., Jones, G. P., \& Polumin, N. V. C. (2006). Multiple disturbances and the global degradation of coral reef: Are reef fishes at risk or resilient? Global Change Biology, 12, 22202234.

WorldFish. (2007). The threat to fisheries and aquaculture from climate change. Policy Brief (p. 8). The WorldFish Center, PO Box 500 GPO, 10670 Penang, Malaysia.

YFSB (Year Book of Fisheries Statistics of Bangladesh). (2017). Fisheries Resource Survey System. Department of Fisheries Bangladesh, Ministry of Fisheries and Livestock, Government of the People's Republic of Bangladesh, 71.

\section{Copyrights}

Copyright for this article is retained by the author(s), with first publication rights granted to the journal.

This is an open-access article distributed under the terms and conditions of the Creative Commons Attribution license (http://creativecommons.org/licenses/by/4.0/). 